\title{
ANALISIS PIRANTI KOHESI LEKSIKAL DALAM TEKS LAPORAN \\ HASIL OBSERVASI OLEH SISWA KELAS VII SMP NEGERI 2 PERCUT SEI TUAN TAHUN PEMBELAJARAN 2017/2018
}

\section{Oleh}

\author{
Meilan Simanjuntak
}

Drs. Basyaruddin, M.Pd.

\begin{abstract}
ABSTRAK
Penelitian ini bertujuan untuk mendeskripsikan wujud penggunaan jenis-jenis kohesi leksikal pada teks laporan hasil observasi siswa kelas VII SMP Negeri 2 Percut Sei Tuan tahun pembelajaran 2017/2018. Penelitian ini merupakan penelitian deskriptif kualitatif. Sumber data dalam penelitian ini adalah teks laporan hasil observasi siswa kelas VII SMP Negeri 2 Percut Sei Tuan. Metode yang digunakan dalam penelitian ini adalah metode deskriptif kualitatif. Instrumen yang digunakan adalah peneliti sendiri (human instrument). Untuk menemukan dan mengklasifikasikan wujud penggunaan dalam jenis-jenis kohesi leksikal digunakan teknik membaca dan mencatat. Hasil penelitian menunjukkan ditemukan bentuk penggunaan jenis kohesi leksikal pada teks laporan hasil observasi siswa kelas VII SMP Negeri 2 Percut Sei Tuan tahun pembelajaran 2017/2018. Jumlah keseluruhan penggunaan yang terdapat dalam teks laporan hasil observasi siswa sebanyak 154 dari keseluruhan jenis-jenis kohesi leksikal.. Terdapat 126 jumlah penggunaan yang tepat yang ditemukan dalam teks laporan hasil observasi siswa dan sebanyak 28 jumlah penggunaan yang tidak tepat ditemukan dalam teks laporan hasil observasi kelas VII SMP Negeri 2 Percut Sei Tuan tahun pembelajaran 2017/2018.
\end{abstract}

Kata kunci: Kohesi Leksikal dan Teks Laporan Hasil Observasi.

\section{PENDAHULUAN}

Pada hakikatnya belajar bahasa adalah belajar berkomunikasi. Oleh karena itu, pembelajaran bahasa indonesia diarahkan untuk meningkatkan kemampuan siswa untuk berkomunikasi secara lisan maupun secara tulisan. Bahasa memiliki fungsi-fungsi tertentu yang digunakan berdasarkan kebutuhan seseorang, yakni sebagai alat untuk mengekspresikan diri, sebagai alat untuk berkomunikasi, sebagai alat untuk mengadakan integrasi dan 
beradaptasi sosial dalam lingkungan atau situasi tertentu, dan sebagai alat untuk melakukan kontrol sosial (Keraf, 1984:3). Manusia dapat berkomunikasi dengan bahasa lisan atau tulisan. Berkomunikasi dengan bahasa lisan maupun tulisan sama-sama bertujuan untuk menyampaikan ide, pikiran, gagasan, pendapat, atau keinginan kepada orang lain, perbedaannya hanya terletak pada cara penyampaiannya saja. Pada bahasa lisan komunikasi disampaikan secara langsung dengan cara diucapkan sedangkan berkomunikasi dengan bahasa tulis disampikan melalui sistem tulisan.

Sebagai salah satu keterampilan berbahasa, menulis digunakan untuk berkomunikasi secara tidak langsung. Menulis merupakan salah satu kegiatan yang harus dilakukan oleh siswa dalam proses pembelajaran Bahasa Indonesia. Melalui kegiatan menulis, siswa akan menjadi lebih aktif dan kreatif dalam menciptakan suatu karya yang baru. Selain itu, siswa dapat belajar untuk mengemukakan ide yang dimiliki melalui tulisan dengan menggunakan gaya bahasanya sendiri. Menulis juga merupakan sarana untuk mengembangkan kemampuan siswa dalam menggunakan bahasa. Itulah sebabnya mengapa pembelajaran menulis diajarkan di sekolah.

Salah satu pembelajaran menulis yang diajarkan di Sekolah Menengah Pertama (SMP) adalah menulis teks laporan hasil observasi. Keterampilan menulis teks laporan hasil observasi harus dikuasai siswa kelas VII karena merupakan salah satu materi yang terdapat dalam silabus Kurikulum 2013. Teks laporan hasil observasi merupakan salah satu jenis teks baru dalam pembelajaran Bahasa Indonesia, oleh karena itu teks ini sangat penting untuk dipahami oleh siswa. Dalam materi menulis teks laporan hasil observasi siswa diharapkan memahami konsep teks laporan hasil observasi dengan struktur pembentuknya yang terdiri atas definisi umum, deskripsi bagian, dan deskripsi manfaat. Selain itu, pada materi ini siswa diharapkan juga dapat memahami unsur-unsur kebahasaan yang ada di dalam teks laporan hasil observasi.

Salah satu wujud kemampuan dari siswa sesuai dengan Kurikulum Sekolah Lanjutan Tingkat Pertama adalah kemampuan menulis wacana atau teks. Penekanan pembelajaran berbasis teks tersebut bukan pada pembahasan wacana atau teks itu sendiri, melainkan pada pengembangan melalui hubungan antarkata dengan kalimat antar kalimat dengan paragraf dan antarparagraf dalam wacana yang utuh atau koheren dengan piranti-pirantinya seperti penggunaan alat-alat kohesi secara tepat.

Keterampilan menulis telah diajarkan di SMP Negeri 2 Percut Sei Tuan, akan tetapi kemampuan menulis teks hasil observasi siswa masih tergolong rendah dan kesalahan berbahasa dalam penulisan masih sering dijumpai terutama dalam penggunaan setiap jenis- 
jenis kohesi leksikal. Hal itu terbukti dari hasil pengamatan penulis ketika sedang melaksanakan kegiatan PPLT di SMP Negeri 2 PercutSei Tuan. Banyak siswa mendapatkan nilai 50 - 70 dalam tugas menulis teks laporan hasil observasi sedangkan nilai KKM yang ditentukan sekolah adalah 75 (masih di bawah KKM). Serta masih banyak terdapat kesalahan penggunaan jenis-jenis kohesi leksikal dalam teks laporan hasil observasi yang ditulis oleh siswa, seperti penggunaan repetisi, sinonim, antonim, kolokasi, hiponim dan ekuivalensi yang berlebihan.

Pembelajaran menulis seharusnya mendapatkan perhatian lebih dalam agar siswa dapat memahami dan menguasai keterampilan ini. Maksud dari mendapatkan perhatian lebih dalam yaitu bahwa dalam belajar menulis, siswa harus diajak dan dilatih menulis secara terus-menerus, secara berkala agar siswa bisa mahir menulis. Latihan menulis di sini tidak hanya sekedar menulis apa yang siswa bisa tetapi juga latihan menulis secara baik dan benar sesuai dengan kaidah tata bahasa Indonesia tetapi meningkatkan pemahaman siswa mengenai kesinambungan dan keserasian dan kepaduan antar kata, kalimat dalam sebuah paragraf.

Menurut hasil penelitian yang telah dilakukan Dwi Prihanto yang berjudul " Analisis Penanda Kohesi pada Karangan Siswa Tingkat Sekolah Menengah Pertama Kelas VIII SMP Muhammadiyah 5 Surakarata." yang menyatakan bahwa Karangan siswa SMP banyak terdapat kohesi yang tidak tepat salah satu nya yang sering ditemui pada kesalahan penggunaan kohesi dalam bidang repetisi.

Begitu pula penelitian yang telah dilakukan oleh Iskandar "Analisis Kohesi Dalam Karangan Siswa Kelas VIII SMP Muhammadiyah Takkalasi Kabupaten Baru.” yang mengatakan Pada kenyataannya sekarang kemampuan siswa dalam karangan kohesif dan koherensif belum dipakai secara menyeluruh.Misalnya dalam menilai latihan mengarang siswa, guru hanya menyoroti bahasa dalam karangan tersebut bukan mempertimbangkan padu atau tidaknya sebuah karangan, sehingga dalam pencapaian tujuan akhir dalam evaluasi karangan secara ideal seperti yang diungkap di atas tidak dapat diperoleh. Aspek-aspek yang membentuk kohesi di dalam teks harus berkesinambungan dan membentuk kesatuan struktur teks agar dapat mendukung koherensi. Apabila urutan progresi pada suatu teks tidak jelas maka akan menyebabkan ambigu dan tidak koherennya suatu teks. Suatu ujaran yang tidak jelas urutan awal, tengah dan akhir bukan merupakan teks yang baik.

Permasalahan ini diambilkarena dari beberapa penelitian yang pernah dilakukan menunjukkan bahwa pemahaman dan penguasaan serta kemampuan menggunakan jenis-jenis kohesi leksikal dimiliki siswa tidak baik. Ketidakmampuan siswa dalam menggunakan jenis- 
jenis kohesi leksikal tampak pada kepaduan antar kata maupun kalimat dalam sebuah paragraf dalam teks yang dibuatnya.

Berdasarkan uraian singkat di atas, peneliti bermaksud melakukan penelitian yang berjudul: Analisis Piranti Kohesi Leksikal Dalam Teks Laporan Hasil Observasi Oleh Siswa Kelas VII SMP Negeri 2 Percut Sei Tuan Tahun Pembelajaran2017/2018.Penelitian ini akan menjelasakan mengenai wujud penggunaan yang terdapat dalam teks laporan hasil observasi karya siswa kelas VII SMP Negeri 2 Percut Sei Tuan.

\section{METODE PENELITIAN}

Metode penelitian adalah cara yang digunakan oleh peneliti dalam mengumpulkan data penelitiannya (Arikunto, 2013: 160). Metode yang digunakan dalam penelitian ini adalah metode deskriptif kualitatif. Boydan dan Taylor (Moleong, 2012 : 4), mengatakan bahwa penelitian kualitatif merupakan prosedur penelitian yang menghasilkan data deskriptif berupa kata-kata tertulis atau lisan dari orang-orang dan perilaku yang dapat diamati. Menurut Moleong (2012: 11), data yang dikumpulkan dalam penelitian deskriptif berupa kata-kata, gambar, dan bukan angka-angka. Metode deskriptif kualitatif dipilih karena masalah yang diteliti berupa data (teks) yang lebih tepatnya dijelaskan dengan menggunakan katakata.Penelitian ini menyajikan data selengkapnya dalam tabel data untuk mendeskripsikan jenis kesalahan kalimat yang terdapat dalam teks laporan hasil observasi siswa kelas VII SMP Negeri 2 Percut Sei Tuan.

\section{HASIL PENELITIAN DAN PEMBAHASAN}

\section{Hasil Penelitian}

Jumlah keseluruhan penggunaan piranti kohesi leksikal sebanyak 154 diantaranya 126 penggunaan yang tepatdan 28 yang tidak tepat. Hal tersebut diperoleh berdasarkan penyeleksian data yang telah dilakukan sebagai bagian dari proses analisis dengan membaca cermat dan berulang-ulang. Wujud penggunaan Kohesi Leksikal dapat dilihat dari Jumlah Penggunaan nya. Jumlah penggunaan Kohesi Leksikal dalam Teks Laporan Hasil Observasi Siswa Kelas VII SMP Negeri 2 Percut Sei Tuan berjumlah 154 yang terdiri dari repetisi, sinonim, antonim, hiponim, kolokasi dan ekuivalensi. Penggunaan tersebut terdiri dari 77 repetisi penuh, 16 repetisi dengan bentuk lain, 13 repetisi ulangan dengan penggantian, 3 sinonim semirip, 2 sinonim selingkung, 4 antonim mutlak dan 2 antonim kutub serta 15 hiponim, 12 kolokasi dan 10 ekuivalensi. 
Tabel Wujud Penggunaan Kohesi Leksikal Penggunaan Kohesi Leksikal Dalam Teks Laporan Hasil Observasi Siswa Kelas VII SMP Negeri 2 Percut Sei Tuan

\begin{tabular}{|c|c|c|c|c|}
\hline NO & $\begin{array}{l}\text { Jenis Kohesi } \\
\text { Leksikal }\end{array}$ & Deskriptor & Jumlah & $\begin{array}{l}\text { Jumlah } \\
\text { Keseluruhan }\end{array}$ \\
\hline \multirow[t]{3}{*}{1} & \multirow[t]{3}{*}{ Repetisi } & Ulangan penuh & 77 & \multirow[t]{3}{*}{106} \\
\hline & & $\begin{array}{l}\text { Ulangan dengan } \\
\text { bentuk lain }\end{array}$ & 16 & \\
\hline & & $\begin{array}{l}\text { Ulangan dengan } \\
\text { penggantian }\end{array}$ & 13 & \\
\hline \multirow[t]{3}{*}{2} & \multirow[t]{3}{*}{ Sinonim } & Sinonim mutlak & - & \multirow[t]{3}{*}{5} \\
\hline & & Sinonim semirip & 3 & \\
\hline & & Sinonim selingkung & 2 & \\
\hline \multirow[t]{4}{*}{3} & \multirow[t]{4}{*}{ Antonim } & Antonim mutlak & 4 & \multirow[t]{4}{*}{6} \\
\hline & & Antonim kutub & 2 & \\
\hline & & Antonim hierarkial & - & \\
\hline & & Antonim majemuk & - & \\
\hline 4 & Hiponim & & 15 & 15 \\
\hline 5 & Kolokasi & & 12 & 12 \\
\hline 6 & Ekuivalensi & & 10 & 10 \\
\hline \multicolumn{2}{|r|}{ Total } & \multicolumn{3}{|c|}{154} \\
\hline
\end{tabular}

\section{Pembahasan Hasil Penelitian}

1. Wujud Ketepatan Penggunaan Kohesi Leksikal Pada Teks Laporan Hasil Observasi Siswa Kelas VII SMP Negeri 2 Percut Sei Tuan Tahun Pembelajaran 2017/2018

Pada penelitian ini penggunaan kohesi leksikal pada teks laporan hasil observasi siswa kelas VII SMP Negeri 2 Percut Sei Tuan terdiri dari repetisi, sinonim, antonim, hiponim, kolokasi dan ekuivalensi. Sumarlam (2003: 35) membagi kohesi leksikal menjadi enam macam yaitu : repetisi (pengulangan), sinonimi (persamaan kata), antonimi (lawan kata), hiponimi (hubungan atas-bawah), kolokasi (sanding kata) dan ekuivalensi (kesepadanan).

1. Repetisi (pengulangan)

Sumarlam, (2003: 35) mengatakan "Repetisi (pengulangan) Merupakan pengulangan satuan lingual (bunyi, suku kata, kata, atau bagian kalimat) yang dianggap penting untuk memberi tekanan dalam sebuah konteks yang sesuai”. Adapun jenis- jenis ulangan atau repetisi berdasarkan data pemakaian bahasa Indonesia seperti berikut. 
a. Ulangan Penuh

Ulangan penuh berarti mengulang satu fungsi dalam kalimat secara penuh, tanpa pengurangan dan perubahan bentuk.

Adapun data tentang ulangan penuh pada penelitian ini adalah sebagai berikut.

(1) Kebun teh adalah kebun yang diolah menjadi teh yang sehat dan dijual di pasar atau ruang makan dan kebun teh banyak manfaatnya dan bisa di minum. (A19)

Pada data (1) diatas termasuk repetisi yaitu pengulangan penuh karena terdapat pengulangan kata kebun teh.

b. Ulangan dengan bentuk lain

Ulangan dalam bentuk lain Terjadi apabila sebuah kata diulang dengan konstruksi atau bentuk kata lain yang masih mempunyai bentuk dasar yang sama.Adapun data tentang ulangan dengan bentuk lain pada penelitian ini adalah sebagai berikut.

(2) Candi Borobudur merupakan warisan budaya Indonesia yang dikenal sampai seluruh dunia. Di dalam candi terletak juga pada ukiran yang indah dan bentuk-bentuknya (A26)

dari data (2) diatas dapat disimpulkan bahwa data tersebut adalah pengulangan dengan bentuk lain karena kalimat pertama dan kalimat kedua diulang dengan bentuk berbeda walaupun pengertian kalimat tersebut sama, yaitu sama- sama menjelaskan mengenai candi Borobudur.

\section{c. Ulangan dengan Penggantian}

Pengulangan dapat dilakukan dengan mengganti bentuk lain seperti dengan kata ganti.Adapun data tentang ulangan dengan penggantian pada penelitian ini adalah sebagai berikut.

(3) Perpustakaan adalah tempat untuk membaca buku. Di sana banyak anak sekolah atau guru untuk membaca semua buku di dalam perpustakaan itu. (A03) 
Pada data (3) diatas terdapat repetisi yaitu ulangan dengan penggantian yaitu penggantian kata Perpustakaan menjadi disana dan itu yang berarti kata disana dan itu juga memiliki arti yang menyatakan perpustakaan..

\section{Sinonim (Padan Kata)}

Sinonimi (padan kata) Merupakan salah satu aspek leksikal untuk mendukung kepaduan wacana (Sumarlam, 2003: 39).Sinonimi berfungsi menjalin hubungan makna yang sepadan antara satuan lingual tertentu dengan satuan lingual lain dalam wacana. Adapun jenis- jenis sinonim adalah sebagai berikut.

a) sinonim mutlak

Sinonim mutlak adalah Kata-kata yang dapat bertukar tempat dalam konteks kebahasaan apa pun tanpa mengubah makna struktural dan makna leksikal dalam rangkaian kata/frasa/klausa/kalimat. Namun pada hasil penelitian mengenai penggunaan sinonim mutlak tidak ada ditemukan pada teks laporan hasil observasi siswa SMP N 2 Percut Sei Tuan.

b) Sinonim semirip

Sinonim semirip berarti kata-kata yang dapat bertukar tempat dalam konteks kebahasaan tertentu tanpa mengubah makna struktural dan leksikal dalam rangkaian kata/frasa/klausa/kalimat tersebut saja.

Adapun data tentang sinonim semirip pada penelitian ini adalah sebagai berikut.

(4) Bunga melati jika tidak dirawat atau diberi pupuk atau air dia akan layu(A06)

Pada data (4) diatas terdapat penggunaan kohesi leksikal yaitu penggunaan sinonim semirip pada kata dirawat dan diberi pupuk karena kata tersebut masih memiliki makna yang sama yaitu perawatan sebuah tanaman. 
c) Sinonim selingkung

Sinonimi Selingkung berarti kata-kata yang dapat saling mengganti dalam satu konteks kebahasaan tertentu saja secara struktural dan leksikal. Adapun data tentang sinonim selingkung pada penelitian ini adalah sebagai berikut.

(5) Kebun teh memiliki pemandangan yang asri dan indah. (A18)

Pada data (5) diatas terdapat penggunaan sinonim yaitu sinonim selingkung yaitu kata asri dan indah masih memiliki makna yang sama.

3. Antonimi (lawan kata)

Sumarlam (2003: 40) mengatakan "Antonimi dapat diartikan sebagai nama lain untuk benda atau hal yang lain; atau satuan lingual yang maknanya berlawanan/beroposisi dengan satuan lingual yang lain”. Menurut Budiman (1981: 3) Antonim dapat dibedakan atas empat macam yaitu:

a) Antonim mutlak

Antonim mutlak adalah antonim yang mempertentangkan makna secara mutlak.Adapun data tentang antonim mutlak pada penelitian ini adalah sebagai berikut.

(6) Sekolah adalah tempat para siswa atau siswi menuntut ilmu. (A34)

Pada data (6) terdapat penggunaan antonim mutlak yaitu terdapat pada kata siswa yang antonim atau lawan katanya adalah siswi.

b) Antonim kutub

Antonim kutub adalah Antonim yang mempertentangkan makna kata secara gradasi atau tingkatan antar makna kata.Adapun data tentang antonim kutub pada penelitian ini adalah sebagai berikut.

(7) Dengan membaca semua buku itu, anak sekolah maupun guru dapat menambah ilmu nya sedikit (A03) 
Pada data (7) diatas merupakan penggunaan antonim kutub yang mempertentangkan makna kata secara tingkatan yaitu terletak pada kata anak sekolah dan guru.

c) Antonim hierarkial

Antonim hierarkial adalah Antonim antara makna kata yang memiliki tingkatan atau jenjang. Namun pada hasil penelitian penulis penggunaan antonim hierarkial tidak ditemukan dalam teks laporan hasil observasi siswa SMP N 2 Percut Sei Tuan.

d) Antonim majemuk

Antonim majemuk adalah sebuah kata yang memiliki antonim lebih dari satu.Namun pada hasil penelitian penulis penggunaan antonim majemuk tidak ditemukan dalam teks laporan hasil observasi siswa SMP N 2 Percut Sei Tuan.

\section{Hiponim}

Sumarlam (2003: 44) mengatakan "Hiponimi merupakan satuan bahasa (kata, frasa, kalimat) yang maknanya dianggap merupakan bagian dari makna satuan lingual lain”. Dalam semantik, hiponim adalah suatu kata atau frasa yang maknanya tercakup dalam kata atau frasa lain yang lebih umum, yang disebut hiperonim atau hipernim. Suatu hiponim adalah anggota kelompok dari hiperonimnya dan beberapa hiponim yang memiliki hiperonim yang sama disebut dengan kohiponim.

Adapun data tentang hiponim pada penelitian ini adalah sebagai berikut.

(8) Di museum banyak berbagai hewan apa saja yaitu kupu-kupu, beruang, jerapah, gajah dan juga burung. (A22)

Pada data (8) diatas terdapat penggunaan jenis kohesi leksikal hiponim yaitu penggunaan hiponim hewan yaitu kupu-kupu, beruang, jerapah, gajah dan juga burung. 


\section{Kolokasi atau sanding kata}

Menurut Sumarlam, (2003: 44). Kolokasi merupakan asosiasi tertentu dalam menggunakan pilihan kata yang cenderung digunakan secara berdampingan. Adapun data tentang kolokasi pada penelitian ini adalah sebagai berikut.

(9) Di dalam candi terletak juga pada ukiran yang indah dan bentuk-bentuknya yang berupa para-para peninggal sejarah nenek moyang mereka. (A26)

Pada data (9) diatas terdapat penggunaan kolokasi atau sanding kata karena disana terdapat pemilihan kata yang digunakan secara berdampingan untuk menghubungkan suatu kalimat yaitu kata berupa.

\section{Ekuivalensi (kesepadanan).}

Ekuivalensi adalah beberapa pernyataan yang memiliki nilai kebenaran yang sama satu dengan yang lainnya sehingga dapat menggantikan dua pernyataan yang saling ekuivalen atau ekuivalensi adalah kesejajaran dalam sebuah kalimat. Dua pernyataan dikatakan ekuivalensi (sama) jika pernyataan tersebut memiliki nilai kebenaran yang sama.Adapun data tentang ekuivalensi pada penelitian ini adalah sebagai berikut.

(10) Manggis buah asli Indonesia yang khas, selain rasa yang manis dan penampilannya yang enak dilihat buah manggis juga memiliki banyak kandungan yang bermanfaat untuk kesehatan (A14)

Pada data (10) diatas terdapat ekuivalensi atau kesepadanan yaitu pada kalimat manggis adalah buah asli di Indonesia, selain rasa yang manis dan penampilannya enak, buah manggis juga banyak manfaatnya. Kalimat ini merupakan kesepadanan yaitu buah manggis tidak bisa dipisahkan dari manfaatnya sepadan dengan banyak nya kandungan yang terdapat di dalam buah manggis. Penggunaan ekuivalensi ini tepat karena penggunaan tersebut sesuai dengan aspek leksikal bahasa. 
2. Wujud Ketidaktepatan Penggunaan Kohesi Leksikal Pada Teks Laporan Hasil

Observasi Siswa Kelas VII SMP Negeri 2 Percut Sei Tuan Tahun Pembelajaran $2017 / 2018$

Ketidaktepatan penggunaan kohesi leksikal merupakan penggunaan kohesi leksikal yang tidak sesuai dengan tata bahasa, ketidaktepatan penggunaan kohesi leksikal terdiri dari ketidaktepatan penggunaan repetisi,sinonim hiponim, kolokasi dan ekuivalensi. Adapun ketidaktepatan penggunaan kohesi leksikal pada teks laporan hasil observasi siswa kelas VII SMP Negeri 2 Percut Sei Tuan adalah sebagai berikut.

1) Repetisi (pengulangan)

Sumarlam, (2003: 35) mengatakan "Repetisi merupakan pengulangan satuan lingual (bunyi, suku kata, kata, atau bagian kalimat) yang dianggap penting untuk memberi tekanan dalam sebuah konteks yang sesuai". Ketidaktepatan penggunaan repetisi merupakan penggunaan kohesi leksikal repetisi yang tidak sesuai dengan tata bahasa. Berikut contoh ketidaktepatan penggunaan repetisi.

(1) Pohon jambu memiliki ciri-ciri batang yang berwarna coklat muda, memiliki daun yang berwarna hijau dan memiliki buah yang berwarna merah. Di dalam buah jambu memiliki biji yang berwarna putih (A32)

Pada data (1) diatas terdapat ketidaktepatan penggunaan kohesi leksikal repetisi ulangan penuh yakni penggunaan kata berulang-ulang yang membuat makna dari kalimat tersebut sulit ditemukan yaitu kata memiliki. seharusnya kalimat yang benar Pohon jambu memiliki ciri-ciri batang yang berwarna coklat muda, daun yang berwarna hijau dan buah yang berwarna merah.

2) Sinonim

Sinonimi (padan kata) Merupakan salah satu aspek leksikal untuk mendukung kepaduan wacana. Berikut contoh ketidaktepatan penggunaan sinonim jenis sinonim semirip. 
(2) Manfaatnya bisa di pelajari yang penting-penting atau yang perlu-perlu ditulis (A16)

Pada data diatas (2) terdapat penggunaan sinonim semirip yang tidak tepat yaitu pada kalimat yang perlu-perlu atau penting-penting seharusnya agar kalimat lebih efektif antara salah satu kata yang perlu-perlu atau yang penting-penting dihilangkan saja sehingga lebih efektif, contohnya Manfaatnya bisa di pelajari yang perlu-perlu ditulis.

3) Hiponim

Sumarlam (2003: 44) mengatakan "Hiponimi Merupakan satuan bahasa (kata, frasa, kalimat) yang maknanya dianggap merupakan bagian dari makna satuan lingual lain”.Ketidaktepatan penggunaan Hiponim merupakan penggunaan kohesi leksikal hiponim yang tidak sesuai dengan tata bahasa. Berikut contoh ketidaktepatan penggunaan Hiponim.

(3) Pohon termasuk makhluk hidup. Pohon juga bisa berkembang biak dengan cara tunas ,biji dan cangkok, dll. (A10)

Pada data (3) diatas terdapat ketidaktepatan penggunaan hiponim yang kurang tepat karena dalam kalimat tersebut terdapat cara berkembang biak pohon yang salah yaitu pada kata 'biji' Seharusnya kalimat yang benar adalah pada Pohon termasuk makhluk hidup. Pohon juga bisa berkembang biak dengan cara tunas, akar, umbi cangkok, dll. Tunas, akar, umbi cangkok merupakan hiponim dari cara pohon berkembang biak.

4) Kolokasi atau sanding kata

Menurut Sumarlam, (2003: 44). Kolokasi merupakan asosiasi tertentu dalam menggunakan pilihan kata yang cenderung digunakan secara berdampingan. Ketidaktepatan penggunaan kolokasi merupakan penggunaan kohesi leksikal kolokasi yang tidak sesuai dengan tata bahasa. Berikut contoh ketidaktepatan penggunaan kolokasi.

(4) Sebelum meletus dia mengeluarkan tanda-tanda gempa bumi bergetar abis bergetar dia mengeluarkan larva yang sangat panas. (A33) 
Pada data (4) diatas terdapat ketidaktepatan penggunaan kohesi leksikal jenis kolokasi atau sanding kata pada kata 'abis'. Perbaikan dari data (32) Sebelum meletus dia mengeluarkan tanda-tanda gempa bumi bergetar setelah bergetar dia mengeluarkan larva yang sangat panas

\section{5) Ekuivalensi (kesepadanan).}

Ekuivalensi adalah beberapa pernyataan yang memiliki nilai kebenaran yang sama satu dengan yang lainnya sehingga dapat menggantikan dua pernyataan yang saling ekuivalen atau ekuivalensi adalah kesejajaran dalam sebuah kalimat. Dua pernyataan dikatakan ekuivalensi (sama) jika pernyataan tersebut memiliki nilai kebenaran yang sama. Ketidaktepatan penggunaan ekuivalensi merupakan penggunaan kohesi leksikal ekuivalensi yang tidak sesuai dengan tata bahasa. Berikut contoh ketidaktepatan penggunaan ekuivalensi.

(5) Manfaat dari bunga matahari adalah untuk menghias tanaman biar supaya biar cantik tanamannya dan bisa dijual ke tukang bunga. (A21)

Pada data (5) diatas terdapat ketidaktepatan penggunaan ekuivalensi, hal itu terjadi karena terdapat penggunaan kalimat yang berlebihan sehingga tidak ekuivalen yaitu pada kata 'biar supaya' seharusnya kalimat yang benar adalah Manfaat dari bunga matahari adalah untuk menghias tanaman supaya cantik tanamannya dan bisa dijual ke tukang bunga.

\section{PENUTUP}

Berdasarkan hasil penelitian dan pemabahasan yang telah diuraikan, maka dapat diambil kesimpulanbahwaWujud dari Penggunaan Kohesi Leksikal dalam Teks Laporan Hasil Observasi Siswa Kelas VII SMP Negeri 2 Percut Sei Tuan jika dilihat dari data kualitatif tersebut, ketepatan penggunaan kohesi leksikal pada teks laporan hasil observasi siswa kelas VII SMP Negeri 2 Percut Sei Tuan termasuk dalam kategori baik dilihat dari segi Ketepatan penggunaan kohesi leksikal berjumlah 81,82\% atau 126 dari 154 jumlah keseluruhan kohesi leksikal dan ketidaktepatan berjumlah 18,18\% atau 28 dari 154 jumlah keseluruhan penggunaan kohesi leksikal.

Wujud penggunaan Kohesi Leksikal dapat dilihat dari Jumlah Penggunaan nya. Jumlah penggunaan Kohesi Leksikal dalam Teks Laporan Hasil Observasi Siswa Kelas VII SMP Negeri 2 Percut Sei Tuan berjumlah 154 yang terdiri dari repetisi, sinonim, antonim, 
hiponim, kolokasi dan ekuivalensi. Penggunaan tersebut terdiri dari 77 repetisi penuh, 16 repetisi dengan bentuk lain, 13 repetisi ulangan dengan penggantian, 3 sinonim semirip, 2 sinonim selingkung, 4 antonim mutlak dan 2 antonim kutub serta 15 hiponim, 12 kolokasi dan 10 ekuivalensi.

\section{DAFTAR PUSTAKA}

Arikunto, Suharsimi. 2013. Prosedur Penelitian: Suatu Pendekatan Praktik. Jakarta: Rineka Cipta.

Iskandar. Analisis Kohesi Dalam Karangan Siswa Kelas VIII SMP Muhammadiyah Takkalasi

Kabupaten Baru. Jurnal:Universitas Muhammadiyah Makasar (diunduh pada 15 januari 2017)

Moleong, Lexy J. 2012. Metodologi Penelitian Kualitatif. Bandung: Remaja Rosdakarya.

Prihanto,Dwi. 2012. Analisis Kohesi Dalam Karangan Siswa Kelas VIII Smp Muhammadiyah

Takkalasi Kabupaten Baru. Jurnal: Universitas Muhammadiyah Surakarta (diunduh pada 15 januari 2017) 